\title{
POSITIVE ORGANIZATIONAL SCHOLARSHIP CONCEPT: AN OVERVIEW AND FUTURE STUDIES ${ }^{1}$
}

\author{
Anselmo Ferreira Vasconcelos ${ }^{2}$
}

http://dx.doi.org/10.1590/1413-2311.179.67731

\begin{abstract}
The purpose of this paper is to provide an overview about the insightful Positive Organizational Scholarship (POS) concept, which is considered as one of the most important management theoretical developments over the past decade. Therefore, it reviews the meaning, scope, domains, major constructs, outcomes, and theoretical overlaps related to POS, as well as providing a critical analysis of this umbrella concept. In doing so, it is expected to contribute to further understanding of POS theoretical richness as a path to the improvement of workplaces. Despite the difficulties and problems discussed here (e.g., few empirical work, validity issues, and some theoretical intersections) under the relatively new POS concept has ever gathered germane knowledge that has helped to explain how organizations improve their dynamics and general outcomes by adopting more constructive approaches. On the other hand, it is exciting to find that POS concept researchers have worked with a sizeable number of constructs, topics, and ideas. This review contributes to the POS concept by closely examining some of its major constructs (fundamentally those ones that are more theoretically and empirically developed) such as compassion, connections and relationships, cooperation, courageous, flourishing, forgiveness, meaningful work, positive deviance, positive motions, resilience, thriving and virtuous aspects. The results reveal a richer understanding about their benefits and challenges, as well as emphasizing new possibilities for future studies.
\end{abstract}

\footnotetext{
${ }^{1}$ Recebido em 08/09/2016, aprovado em 18/07/2017.

2 Pesquisador independente (Brasil)-afv@uol.com.br
} 
Key-words: Connections and Relationships. Cooperation. Meaningful Work. Positive Deviance. Positive Emotions.

\section{O CONCEITO DE ESTUDO ORGANIZACIONAL POSITIVO: UMA VISÃO GERAL E FUTUROS ESTUDOS}

\section{RESUMO}

O objetivo deste trabalho é fornecer uma visão geral sobre o conceito de Estudo Organizacional Positivo (EOP), que é considerado como um dos mais importantes desenvolvimentos teóricos de gestão ao longo da última década. Portanto, analisa-se o significado, alcance, domínios, principais construtos, resultados e sobreposições teóricas relacionadas ao EOP, bem como se efetua uma análise crítica desse abrangente conceito. Ao fazê-lo, espera-se contribuir para uma maior compreensão da riqueza teórica do EOP, como um caminho para a melhoria dos locais de trabalho. Apesar das dificuldades e problemas discutidos aqui (por exemplo, poucos trabalhos empíricos, questões de validade e algumas intersecções teóricas), sob esse relativamente novo conceito já se reuniu conhecimento relevante que tem ajudado a explicar como as organizações melhoram as suas dinâmicas e os resultados gerais através da adoção de abordagens mais construtivas. Por outro lado, é excitante constatar que os pesquisadores do conceito de EOP têm trabalhado com um considerável número de construtos, tópicos e idéias. Essa revisão contribui para o conceito EOP através do exame minucioso de alguns de seus principais construtos (fundamentalmente aqueles que são teórica e empiricamente mais desenvolvidos), tais como: compaixão, conexões e relacionamentos, cooperação, coragem, prosperidade, perdão, trabalho com significado, desvio positivo, emoções positivas, resiliência, progresso e aspectos virtuosos. Os resultados revelam uma compreensão mais rica sobre seus benefícios e desafios, bem como se enfatizam novas possibilidades para futuros estudos.

Palavras-chave: Conexões e relacionamentos. Cooperação. Trabalho Significativo. Desvio Positivo. Emoções Positivas.

\section{EL CONCEPTO DE ESTUDIO ORGANIZACIONAL POSITIVA: UMA VISIÓN GENERAL Y LOS ESTUDIOS FUTUROS}




\section{RESUMEN}

El objetivo de este estudio es proporcionar una visión general del concepto de Estudio Organizacional Positiva (EOP), que se considera uno de los desarrollos teóricos más importantes de la gestión en la última década. Por lo tanto, analizamos el significado, alcance, áreas, las principales construcciones, resultados y solapamientos teóricos relacionados con EOP, así como lleva a cabo un análisis crítico de este concepto. Al hacer esto, esperamos contribuir a una mayor comprensión de la riqueza teórica de EOP, como una forma de mejorar los lugares de trabajo. A pesar de las dificultades y los problemas discutidos aquí (por ejemplo, algunos estudios empíricos, problemas válidos y algunas intersecciones teóricas), bajo este concepto relativamente nuevo se ha reunido el conocimiento relevante que ha ayudado a explicar cómo las organizaciones a mejorar su dinámica y los resultados generales mediante la adopción de enfoques más constructivos. Por otro lado, es interesante ver que los investigadores de la EOP han trabajado con una serie de constructos, temas e ideas. Esta opinión contribuye al concepto EOP través de un minucioso examen que toma algunas de sus principales construcciones (sobre todo los que son teóricamente y empíricamente más desarrollada), tales como la compasión, conexiones y relaciones, la cooperación, el valor, la prosperidad, el perdón, trabajar desviación significativa y positiva, emociones positivas, la resistencia, el progreso y aspectos positivos. Los resultados revelan una comprensión más rica de sus beneficios y desafíos, así como enfatizan nuevas posibilidades para futuros estudios.

Palabras-clave: Conexiones y Relaciones. Cooperación. Trabajo Significativo. Desviaciones Positivas. Emociones Positivas.

\section{INTRODUCTION}

Until recently the positive phenomenon was regarded as a neglected topic in Organizational Studies (WRIGHT; CROPANZANO, 2004), but it has gained momentum among researchers, which have examined its nuances and features particularly linked to organizational life (CAMERON et al., 2011). Since the publication of the seminal book, Positive Organizational Scholarship - POS (CAMERON et al., 2003), the field of OS has gained refreshing and invigorating ideas. As a consequence of outstanding academicians' 
insights and investigations, POS, which is heavily grounded on positive lens and perspectives, has provided new pathways to the study of organizational life. What it is singular on the study of POS is the fact that the researchers do not absolutely disdain the negative approaches that usually shape the organizational studies, but they help somewhat to highlight the search for positive values, organizational dynamics and systems. Stated differently, it is important to recognize that "the study of positive phenomena is not wholly one-sided, because the positive and negative are often causally intertwined" (CAMERON, 2007, p. 129).

The notion of positiveness is based on the assumption that human beings cultivate an intrinsic desire toward self-realization in order to express their full capacities (FINEMAN, 2006, p. 272). Nevertheless, this author also ponders that "Positive experiences, learning, and change are tied to negative occurrences and events, as well as to positive ones" (FINEMAN, 2006, p. 275). Fredrickson (2009, p. 23) adds that negativity and neutrality tend to constrain your experience and knowledge of the world, whereas positivity does exactly the opposite. Referring to the "gloom vision" that permeates the mainstream of management theory, Ghoshal (2005, p. 86) warned that the positive approach would not progress unless scholars shifted their efforts toward branching out into new research streams and took the risks. There is no denying that positivity offers an appealing vision, particularly for those disenchanted with the excessive materialism of advanced economies and organizations that show no compassion or sensitivity in relation to their members. Hence, change urged by the positive potential that therein lies inside us may prompt to attainable new futures (FINEMAN, 2006, p. 273). In fact, the effects of positive thinking have been highly acknowledged by many stances, but it is fair to admit that they "still have not reached the point where we truly believe we can create our own realities with our thoughts and anticipatory images" (KRAHNKE; COOPERRIDER, 2008, p. 23).

Admittedly there are several reasons to investigate positive phenomena. For instance, Cameron et al. (2003, p. 370) argue fundamentally that the simple fact that humankind, and organizations, get the feat of thriving and flourishing even when exposed to difficult, threatening, ambiguous, and turbulent conditions is undeniably the prove of the power derived from positive phenomena when triggered toward mitigating and overcoming the more impactful negative events and factors. Furthermore, organizations have already realized the benefits associated with "building a positive work context". In effect, it is perceived that "a positive work environment can result in many different desirable work outcomes, such as more favorable job attitudes and increased work performance" 
(VALENTINE et al., 2011, p. 355). Fredrickson (2009), in turn, argues that positivity is more profound and embraces a range of positive emotions such as appreciation, love, joy, hope, and gratitude. She suggests that positivity changes the contents, the scope and the boundaries of our minds. Further, it can widen the extent of possibilities that we envision in our lives.

For Fredrickson (2009, p. 21), "positivity opens us. The first core truth about positive emotions is that they open our hearts and our minds, making us more receptive and more creative". In addition, she proposed that positivity has the power of transforming us for the better. In summary, Fredrickson $(2009$, p. 25$)$ notes that "positivity broadens and builds. It transforms people and helps them become their best. And when at their best, people live longer. That's one fascinating implication of the broaden-and-build theory".

Regardless of the lens of analysis (i.e., cognitively, emotionally, behaviorally, physiologically or socially), the fact is that "human systems tend to prefer exposure to the positive, so they develop a natural tendency toward positive change" (CAMERON, 2008, p. 13). As a result, there exists a bias toward the positive that shapes human beings especially in their thoughts, judgments, emotions, language, interactions, and physiological functioning. By and large, the negative is construed as signal of pathological or anomaly usually requiring punctual (positive) interventions. Therefore, "A tendency toward the positive appears to be a natural inclination, and empirical evidence suggests that positivity is the preferred and natural state of human beings, just as it is among other biological systems" (CAMERON; SPREITZER, 2012, p. 6).

On the other hand, POS is strongly in debt with the positive psychology science, which focuses in turn on positive qualities at the subjective, individual and group levels. According to Seligman and Csikszentmihalyi (2000, p. 5), positive psychology enables, at the subjective level, valued subjective experiences such as well-being, contentment and satisfaction (in the past); hope and optimism (for the future); and flow and happiness (in the present). At the individual level, it refers to positive individual traits, namely, the capacity for love and vocation, courage, interpersonal skill, aesthetic sensibility, perseverance, forgiveness, originality, future mindedness, spirituality, high talent, and wisdom. Finally, at the group level, it encompasses the civic virtues and the institutions that move individuals toward better citizenship: responsibility, nurturance, altruism, civility, moderation, tolerance, and work ethic. In a few words, positive psychology relies on three aspects, namely, the study of positive emotion, the positive traits, particularly the strengths, virtues, and abilities, and the study of the positive institutions such as families, schools, business, communities, and societies. Seen in this way, psychology is not just concerned with the study of disease, 
weakness and damage, but also with the study of happiness, strength and virtue (SELIGMAN, 2003). Even more noteworthy is the understanding that "In general, the workplace is a natural home for positive psychology and of course positive organizational scholarship, although a close look suggests that some workplaces more than others consistently celebrate virtuosity" (PETERSON; SELIGMAN, 2003, p.25). To some degree, POS is regarded as a cousin of the Positive Psychology movement (DUTTON et al., 2005).

Taken as a whole, it is undeniable that research on POS is important, given that positive phenomena in and through organizations may explain variance that has largely been ignored in previous organizational research. Moreover, by adopting a positive lens one may disentangle many research questions and relationships that have not been appropriately addressed or even neglected by scholars. It is also posited that by studying positivity in individuals and in organizations one may find fertile territory for appropriate understanding of the mechanisms and outcomes underlying the inclination toward positive (CAMERON; SPREITZER, 2012, p. 7). Despite the acknowledgement obtained so far from academic community, after more than a decade of POS introduction, it is pertinent to ascertain its outcomes and contributions to organizational studies. Thus, the purpose of this paper is to provide an overview about the insightful POS concept, which is considered as one of the most important management theoretical developments over the past decade. In this sense, a review of relevant literature of a subject presupposes to focus on what is already known, unknown and what are the cutting-edge theoretical issues (PATTON, 2002). Therefore, it reviews the meaning, scope, domains. In addition, it identifies the major constructs (i.e., those ones that are target of more intense investigation and/or theoretical refinement), outcomes and theoretical overlaps related to POS, as well as providing a critical analysis of this umbrella concept. In doing so, it is expected to contribute to further understanding of POS theoretical richness as a path to the improvement of workplaces. Unlike previous works (e.g., CAMERON et al., 2003; CAMERON; SPREITZER, 2012), which explored a set of potential constructs, this is most likely the first endeavor to focuses on what has indeed gained ground so far.

\section{SOME PARTICULARITIES OD THE POS CONCEPT}

Again, POS is seen as an umbrella concept that embraces distinct approaches in organizational studies permeated by the notion of the positive (CAMERON; SPREITZER, 2012). POS is a new movement in organizational science dedicated to the study of the 
dynamics that lead to exceptional individual and organizational performance, particularly to capabilities such as human strength, resilience, restoration, and vitality. Essentially, "POS is committed to documenting, measuring, and explaining unusually positive human experiences in organizations, and in doing so, contributing to the verifiable body of knowledge about positive conditions in organizations" (CAMERON; CAZA, 2004, p. 734). POS adopts a broad interdisciplinary view by drawing from psychology, organizational theory, sociology, anthropology, and social work (DUTTON et al., 2005). Accordingly, POS researchers have yielded meaningful and rich pieces of work that help understand the dynamics of organizational life. Cameron et al. (2003, p. 370) propose that the discipline of POS enables researchers look at "the phenomena that are associated with flourishing, vitality, virtue, meaning, and life-giving dynamics".

Nonetheless, what is admirable in the POS concept is that it does not disdain other sensible aspects of corporate life such as avoiding tragedy or failure, coping with setbacks or misfortune (CAMERON; CAZA, 2004). Broadly speaking, Dutton et al. (2005, p. 7) suggest that it includes at least four domains, namely: (1) virtuous processes, strengths, and positive organizing - it focuses on individual and organizational virtues, integrity, compassion, resilience, wisdom, human strengths and positive identity; (2) upward spirals and patterns of positive change - it embraces the work on appreciative inquiry, positive deviance, positive emotions, knowledge creation and positive leader development; (3) positive meanings and positive connections - such domain is dedicated to the dynamics of vitality and energy in organizations, relationships, cooperation and creativity; e (4) structural and institutional aspects of POS - it involves the work on developing and reproducing organizational designs that enable positive dynamics and outcomes.

\subsection{POS FOCUS, GROUND, AND CONCERNS}

Therefore, it appears that the cornerstone of the POS concept is to build on positive experiences or, in other words, to improve the human condition. Even though the opposite takes place, it serves as a foundation to elicit positive lessons and principles. Rather,

POS draws from the full spectrum of organizational theories to understand, explain, and predict the occurrence, causes, and consequences of positivity. POS expands the boundaries of these theories to make visible positive states, positive processes, and 
positive relationships that are typically ignored within organizational studies (CAMERON et al., 2003, p. 5).

POS is also seen as a new approach to clarify the human dynamics within organizations (FREDRICKSON, 2003a). It focuses fundamentally on aspects that are judged as highly positive in organizations and brings about "the very best of human condition and the most ennobling organizational behaviors and outcomes" (SPREITZER; SONENSHEIN, 2003, p. 223). Furthermore, Dutton et al. (2005) emphasize that it covers dynamics in organizations (e.g., life-building, capability-enhancing, and capacity-creating) that enable human strengths, virtues, resilience, healing, vitality, and thriving, as well as engendering optimal states on individuals, groups and organizations. Under such an understanding, therefore, it tends to be conducive to several positive outcomes such as achieving human excellence in organizations, unlocking latent potential, and identifying possibilities in people and systems that can be highly beneficial to employees and organizations likewise. Importantly, it must be pointed out that POS is grounded on a full spectrum of organizational theories.

POS focus on the positive and affirmative means asking questions about what individual and organization conditions (and their interactions) account for valued human conditions such as resilience, vitality, thriving, fulfillment, transcendence, courage, flourishing, integrity, wisdom, as well as other individual and collective virtues and strengths. POS re-emphasizes the importance of outcomes such as well-being, citizenship, and health not only as means to desired end of strong economic performance, but also as ends worthy of explanation on their own (DUTTON et al., 2005, p. 6).

As expected, some questions are of particular interest for POS research such as what goes right in organizations, what yields life-giving, what is felt as good, what is inspiring and what leads to joy and inspiration, among others. It is also dedicated to strike a balance about factors involving: competition, problem solving, reciprocity, adversarial negotiation, uncertainty, resistance to change, legal contracting, or financial capital as the key indicator of worth with more positive and elevating dynamics (CAMERON, 2007, p. 129). Anyway, it is worth underlying that the POS concept is not value-neutral. On the other hand, 
POS is not seen exactly as a new field of investigation; perhaps, it is more suitable to state that "it is a coalescing force" that encompasses themes, perspectives, and variables that were dispersed, underdeveloped or even ignored in scientific investigation. It is built on a eudaemonic tenet and, in doing so, it presupposes that all human systems should be conducive to achieving the highest aspirations of humankind as well as excellence and goodness "for its own sake". By adopting an affirmative bias, it engenders positive states and outcomes in relation to energy, climate, relationships, communication and meaning for individuals and organizations (CAMERON; SPREITZER, 2012). Put in another way, POS represents an expanded perspective given that it embraces ideas of goodness and positive human potential. Furthermore, it is concerned with the enables (e.g., unselfishness, altruism, contribution without regard of self) and the outcomes or effects (e.g., vitality, meaningfulness, exhilaration, and high-quality relationships) associated with positive phenomena (CAMERON et al., 2003, p. 4).

In addition, POS is inspired by a positive lens, positively deviant performance, an affirmative bias and the examination of virtuousness or the best of the human condition. It also advocates that organizations are the loci where one must enable the "collective strength and capability-building" (CAMERON; MCNAUGHTAN, 2014, p. 457). In a related vein, Nilsson (2015) suggests that POS could become a social change paradigm if it engages with dimensions such as legitimacy, embedded agency, the institutional nature of roles, boundaries, and practices. He believes that the adoption of a more institutionally embedded lens could take POS researchers to develop some insights about when positive practices may constrain or reinforce negative organizational experiences and social outcomes. Hence, POS pays attention to the understanding related to the integration of positive and negative conditions, not merely with an absence of the negative. As a result, "The ways in which difficulties and challenges are interpreted, managed, and transformed to reveal the positive is in the domain of POS" (CAMERON; CAZA, 2004, p. 732). Nonetheless, "more often than not, POS focuses on that which is unexpectedly positive" (CAMERON, 2005, p. 12). In summary, POS is concerned with "how organizations function when they are at their very best” (QUINN; WELLMAN, 2012, p. 759).

\subsection{POS BENEFITS}

Researchers have emphasized several benefits associated with POS concept. For example, it is posited that POS has the capability of providing an expanded view about how 
organizations may create sustained competitive advantage. It is also advocated that such result may be achieved by unlocking certain capacities such as meaning creation, relationship transformation, positive emotion cultivation, and high-quality connections. To a large extent, POS researchers are very optimistic about the contribution of POS benefits. For them, it is able to provide "a unique conceptual foundation for understanding how and why organizational strategies have their effects on human behavior in the workplace" as well as "why some strategies and dynamic capabilities may be more generative than others" (CAMERON et al., 2003, p. 10). In addition, POS researchers argue that it offers a whole view in which organizations and their actors are perceived as capable of carrying out exceptional performance even in the face of obstacles (SUTCLIFFE; VOGUS, 2003).

Alluding to the effects of positive emotions, which plays a key role in POS concept, Fredrickson (2003a) suggests that positive emotions can help to transform organizations by broadening people's habitual modes of thinking and making organizational members more flexible, emphatic, creative and so on. The author proposes that by cultivating positive emotions one may find positive meaning in the daily work experiences. Overall, one must consider that "POS serves a critical theory function to make important contributions to organization science. It highlights the importance of the positive aspects of organizational life" (CAZA; CAZA, 2008, p. 29).

\section{MAJOR CONSTRUCTS}

Myriads of topics and issues have been attributed to the POS concept umbrella. Nonetheless, this section intends to cover only some constructs related to it, that is, those ones that are more theoretically or empirically developed. Such an outcome is derived from the systematic readings and searching of the words "positive organizational scholarship" and related constructs on sources like ProQuest (i.e., since 2003), POS key authors' research output as well as the Center for Positive Organizations' website material. As a result, I gathered findings and theoretical developments of this topic on an ongoing basis. Taken as a whole, one expects to provide a bigger picture about the state of art of POS and its possibilities.

\subsection{COMPASSION}


Perhaps the construct of compassion is the most explored by POS researchers. Many scholars have written about the beneficial initiatives associated with compassion in the workplace (e.g., BOYATZIS et al., 2006; CASSELL, 2005; FROST, 1999; GEORGE, 2014; SOLOMON, 1998; HILL; STEPHENS, 2003; KANOV et al., 2004; KARAKAS; SARIGOLLU, 2012; KRIEGER; HANSON, 1999; LENNICK; KIEL, 2005; MADDEN et al., 2012; RYNES et al., 2012; SHAHZAD et al., 2014). I am more interested in exploring here the contour of organizational compassion, so to speak, regarding that it is seen as a process whereby "organizational members collectively notice, feel, and respond to pain within their organization" (KANOV et al., 2004, p. 810). When it is present in organizational environments, it indicates that "the system's life-sustaining quality" (DUTTON, 2003a) is working in a more sensible manner. Further, it appears that the presence of compassion, experience gratitude or witness forgiveness inside organizations may nurture or reinforce the cycle (CAMERON et al., 2004). Organizations are frequently associated with sources of pain and suffering; therefore, organizational compassion may mitigate such feelings.

Research supports the notion that experienced compassion in work organizations is related to positive emotions and affective organizational commitment (LILIUS et al., 2008, Study 1). The authors also identified (Study 2) several types of suffering that trigger compassion at work such as serious illness of oneself or a loved one; death of a colleague or loved one; family or personal issues; ill patients in the hospital/patient and family interactions; employees who are treated in the role of patients/patient families by others in the hospital; and work stress. Furthermore, this investigation revealed that most common forms of compassion at work were giving emotional support, giving time or flexibility and giving material goods. Broadly speaking, research suggests that compassion is comprised of three interrelated elements, namely: noticing another's suffering, feeling empathy for the other's pain and responding to the suffering in some way. Findings also show that there are at least three ways of seeing compassion in organizations: (a) compassion as a way of interpersonal work - it is construed as a form of everyday interpersonal interactions that takes place in organizations; (b) compassion as narrative - it is identified in the language and stories in ways that help people make sense of pain and make meaning of their experiences at work; and (c) compassion as organizing - it comprises a collective accomplishment through processes that create, maintain and dissolve social units (FROST et al., 2006a). To a large extent, compassion has a healing potential and, as such, it contributes to enhance organizations' social fabric (i.e., the pattern of the quality of relationships between people in an organization) (DUTTON et al., 2007). 
Fundamentally, the notion of compassion evokes "the value of the common good" by emphasizing a commitment among people. Hence, "compassion in organizations is behavior that is other-focused at its core" (DUTTON et al., 2007, p. 116). There is no doubt that the workplaces can be transformed by compassionate actions (FROST et al., 2006b). By drawing on three broad areas of organizational theory (i.e., emotion, structuration, and resource-based views), Dutton et al. (2006) investigated the story of the organization's response to a fire ignited at the student apartments near a university business school campus, particularly focusing on the key events of the narrative that served as touchstones for an induced theory of compassion organizing. Their analysis found compassion organizing as an outcome of structures of the organization (the social architecture), the agency of individuals who were engaged in the process (activation and mobilization) and emergent features (structural and symbolic). Taken together, these three elements provide the foundation of a theory of compassion organizing. Going further, POS researchers suggest that compassion under an organizational process perspective - can be institutionalized for both rational and symbolic reasons. Therefore, in terms of rational side, organizations can employ the emotionwrought processes on a daily basis in order to help minimize the uncertainties linked to suffering that erupts in an organization. Whereas on the symbolic side, the institutionalization of compassion aims at preserving legitimacy for actions and actors that embrace employee's suffering as a sort of collective achievement. Such mechanisms imply two major forms, namely: designated roles and formal programs (LILIUS et al., 2012). In a related vein, a work by Simpson et al. (2015) focused on to the context of the flood crisis of 2011 in Brisbane, Australia. Their investigation examined particularly (a) the resulting vulnerability experienced by employees during the flood and (b) employees' attitudinal, emotional and behavioral reactions toward their organization's responses. Researchers analyzed the descriptions of characters and experiences, the narratives $(N=25)$ of the experience of compassion dynamics at both the individual and collective level. Findings identified three types of organizational responses to the flood: compassionate care $(N=16)$, neglect $(N=6)$, and an ambiguous organizational response $(N=3)$. They noted that organizations with a high capacity for care and quickly communication with their employees could be regarded suitable to transformed or conscious capitalism. By contrast, some limitations have been linked to the theory and research on compassion inside organizations: the focus on compassion as a psychological state rather than a social relational construct, the tendency to neglect power dynamics inherent in compassion relations and the tendency to neglect power dynamics inherent in compassion relations (SIMPSON et al., 2014, p. 356). Thus far, research on 
organizational compassion has predominantly been conducted by means of qualitative approach.

\subsection{CONNECTIONS AND RELATIONSHIPS}

Admittedly the quality of human connections and relationships impact the organizational environments. As rightly noted by Dutton and Heaphy (2003, p. 263), "human connections in organizations are vital". More specifically, the quality of such connections among organizational members may be life-giving or life-depleting depending on the context where they take place. When high-quality connections with others are noticed, it is likely that there will be a co-construction of identities that are valued by all organizational members. Similarly, both energy and vitality of individuals and organizations are identified on all levels of connections (i.e., among, between organizational members, and toward people outside). Nonetheless, low-quality connections tend to generate undesirable effects on both well-being of individuals and organizations such as fearful toll on energy and well-being, distrust and disregard of the other's worth, reduced sense of humanity, competence, worth, capability, knowledge, motivation, commitment, and emotional reserves. In contrast, by cultivating positive connections one creates antidotes to the corrosive relationships that we are subject to face at work, supportive connections that may reduce the stress and anxiety, safe harbors to rebuild our sense of worth and dignity, among other benefits (see DUTTON, 2003b, for an interesting and comprehensive analysis).

In other words, work relationships can be characterized as a generative source of enrichment, vitality and learning that helps individuals, groups and organizations grow, thrive, and flourish. Otherwise, they can yield toxic and corrosive sources of pain, depletion and dysfunction. Sustainable organizational performance and effective individual development relies on the quality of relationships among people at workplaces (RAGINS; DUTTON, 2007). Although POS theorists have remarked the importance of enabling positive relationships inside organizations and, accordingly, the book Exploring Positive Relationships at Work: Building a Theoretical and Research Foundation (RAGINS; DUTTON, 2007) is a valuable work. In this sense, Blatt and Camden (2007) identified that connections with other people is a relevant aspect to a sample of veteran temporary employees to go to work. Findings revealed that positive connections helped to cultivate community when involved inclusion, a felt sense of being important to others, experienced mutual benefit and shared emotions. 
Golden-Biddle, GermAnn, Reay, and Procyshen (2007) investigated Wetoka Health Unit in Alberta, Canada, and found that the focus on the symbolic meaning of positive relationships contribute to identify how people create and express respect, positive regard, and purposeful work, even during chaotic times. Along related lines, Carmeli, Brueller, and Dutton, (2009) found evidence that positive work relationships played a key role to shape perceptions of psychological safety and learning behaviors in the workplaces. In other study, Carmeli and Gittell (2009) also corroborated that high-quality relationships were significantly associated with psychological safety. Findings showed that the forms of high-quality relationships identified in relational coordination, i.e., shared goals, shared knowledge, and mutual respect helped to the development of psychological safety by increasing the feeling of safety when one's expresses concerns about errors and problems. In turn, Brueller and Carmeli's study (2011) identified that high-quality relationships between the team and its customers were positively associated with team learning processes. Another study also identified the importance of connectivity on decision comprehensiveness in order to enable resilience (i.e., self-efficacy and adaptive capacity; CARMELI; FRIEDMAN; TISHLER, 2013). In a related vein, a recent work by Caillier (forthcoming) reveals that positive workplace relationships in the public sector equip employees with the support and resources to perform their jobs well. In light of it, government workers likely perceive that they are making a greater impact on society. This study also shows that positive workplace relationships are linked to commitment. In addition, researchers suggested that the need for examining other vital aspect toward building positive relationships, that is, trust (PRATT; DIRKS, 2007). On the whole, there remains the need for further empirical evidence to pinpoint other aspects related to this topic.

\subsection{COOPERATION}

Cooperation has been one of the most studied topics in organizational studies, particularly by business strategy and innovation scholars. Indeed, there would not be a foreseeable future for humankind without the strength of cooperation. Actually, "humanity has yet to learn a lot about collaborative capacity in creating our future - a future that can sustain the rich and diverse life on the planet and a thriving human spirit" (KRAHNKE; COOPERRIDER, 2008, p. 18). Enabling a high level of cooperation is a vital procedure for organizations to survive and prosper. For example, it has been conceptualized that compassion at work resides on the functioning of the three pillars of the organizational 
capability for cooperation: (a) the creation of renewable resources - it implies in building trust, felt connection, and positive emotions; (b) shared values and beliefs - it involves the acts and attitudes of dignity and respect, the value of the common good, and the interdependence; and (c) the need for cultivating critical relational skills - it comprises emotional attunement and enabling skills (DUTTON et al., 2007). Today's organizations usually exhibit more interdependent job roles, their organizational structures tend to be less hierarchical, managerial practices are based on employee involvement and the cooperation with fellow coworkers (that transcend their formal job description) occurs daily. Overall, such practices of cooperation nourish organizational functioning (FLYNN, 2006).

In this sense, researchers propose that "new designs in transformative cooperation are energized by positive emotions, which set the stage for unlimited potential for growth and development that moves outward into the community and society at large" (SEKERKA; FREDRICKSON, 2007, p. 164). It is believed that transformative cooperation should be seen as a platform to build shared values and mutual benefits for all involved. Further, by working in a cooperative way - and employing positive experiences as levers for development - one may lead to the creative thinking to envision an innovative future. And this process may be triggered by joint ownership and buy-in arrangements, which culminates in transformative cooperation (SEKERKA et al., 2012). Thus, subjective construal and evaluation of helping behavior is a sort of phenomenon of great interest to researchers that search for a better understanding of employee cooperation (FLYNN, 2006).

\subsection{COURAGEOUS PRINCIPLED ACTION}

Organizations need to change in order to produce more healthy indicators and pleasant internal environments. Research on courage has gained ground perhaps because it is taken for granted that without authentic acts of courage one would not have substantial change inside organizations. Simply put, "in contemporary work, courage is not simply the greatness of leadership of the goodness of moral authority, but rather is a lens into strength, skill, and agency in organizations" (WORLINE et al., 2002, p. 319).

Courageous initiative has the potential to transform basic aspects within companies such as people's sense of agency in their work, the quality of connections between organizational members, the whole organization through changing people's participation and felt connection to the organization's mission and goals (WORLINE et al., 2002). Put another way, "courageous principled action, by breaking the existing organizational frame, unleashes 
social dynamics that may unlock the possibility for positive spirals and thus may contribute to change in organizations" (WORLINE; QUINN, 2003, p. 139). On the other hand, the failure of putting into practice acts of courage inside organizations may lead to failures in general performance. Thus, to meet the challenges of the contemporary marketplace, organizations need to find ways to foster courage in all levels (WORLINE et al., 2002).

Worline (2012) suggest two germane research questions, that is, whether the acts of courage in organizations are lacking or are simply overlooked. In this sense, research by Koerner (2014) explored the intersection of workplace courage and identity processes. By using narrative analysis supplemented by grounded theory procedures this study identified five storylines in the 89 courageous acts described by the interviewees. Overall, the five storylines covered the themes of endurance, reaction, opposition, creation, and no courage. Results also found three components of courage in the accounts: morally worthy goal, risk/threat/obstacle, and intentional action. Another study explored by means of a qualitative approach the perceptions of managerial courage, lack of managerial courage or no need for managerial courage held by five general managers and their close collaborators. Interestingly, 57 critical moments cluster permeated several specific issues: making merger decisions, stakeholder mobilization, negotiating merger agreements, completing the hiring process for general management's positions, and integrating the entities following the merger. Moreover, the major difficulties/risks were related first to the appointment of the new general management and second to the mobilization of stakeholders, whereas participants perceive courage to be manifested to a greater extent in the negotiation of the merger agreement and the appointment of the new general management. Finally, two categories of critical moments were found. The first was related to courage and consisted of two types of managerial moral courage: courage to act and courage to be. Whereas the second, related to non-courage, also consisted of two types: lack of courage and no need for courage (HARBOUR; KISFALVI, 2014).

Other investigation based on 94 interviews and conducted with a wide variety of employees who witnessed or undertook courageous action found evidence that workplace courage is linked to a two-stage process: (a) actors first determine their level of personal responsibility to respond to a challenging situation and then (b) determine the potential social costs of acting. Twenty-seven interviewees could only recall one work-related incident, yielding a final sample of 161 incidents. Findings reported that courageous action were intertwined with four main types of challenging events, namely, abusive power, noticed errors, ambiguity, and someone in need (SCHILPZAND et al., 2015). Researchers have also 
focused on other features of courage in the workplace. For instance, Sekerka et al. (2009) propose a new construct labeled as professional moral courage (PMC). By employing two methods of analysis, they found a measure of PMC derived from five dimensions, namely: moral agency, multiple values, endurance of threats, going beyond compliance, and moral goals. Similarly, PMC is linked to the presence of five themes: (1) moral agency - it denotes a predisposition to be a moral agent; (2) multiple values - it implies to use multiple value sets to determine moral action; (3) endures threat - it prompts to face danger or threat, yet pursues moral action; (4) beyond compliance - it applies rules but also goes beyond compliance to consider what is right, just and appropriate; and (5) moral goal - it urges to complete tasks with the application of moral principles to achieve a moral outcome. In addition, qualitative analysis identified four personal governance practices and/or competencies related to PMC: emotional signaling, reflective pause, self-regulation, and moral preparation (SEKERKA, 2010).

\subsection{FLOURISHING}

Although flourishing is a promising construct for POS concept, little has been developed until now. That said, flourishing is a highly wished goal. Apparently, flourishing is not restrained by happiness or satisfaction with life evaluations. It is advocated that people who flourish tend to be highly engaged with their families, work and communities. Furthermore, they seem to be inspired by a sense of purpose and it constitutes a noble goal. Flourish demands basically the desire of transcending self-interest to share and celebrate goodness in others and in the natural world. Importantly, it is not seen as a solo endeavor given that nobody reaches his or her full potential without the others' help and support. By and large, a person who usually flourishes cultivates warm and trusting relationships with other people (spouse or romantic partner, close friends, family, etc. (FREDRICKSON, 2009).

However, it is worth remembering that the states of human excellence and flourishing are entangled with difficult and challenging circumstances rather than only idyllic and pleasurable circumstances (CAMERON, 2007). To Bono et al. (2012), flourishing at work embraces employees thriving (e.g., vitality and learning), happiness (e.g., positive moods and emotions) and engagement (e.g., job satisfaction and self-determined motivation). They identified two pivotal traits correlated to employee flourishing, that is, extraversion and core self-evaluations. The analysis of behavior, attitudes, emotions and outcomes experienced by people who show high level in these traits suggests that they flourish at work (because of 
their personality) and usually have a positive approach to the self, others, work situations as well as tend to take a proactive approach in the workplace, especially in novel or challenging situations. The authors propose that flourishing is related to individuals who prosper at work (i.e., happy, engaged, self-motivated, successful, and learning). It appears that job performance plays an important role in employee flourishing, but it is not considered as a defining element. Whether flourishing is perceived as a noteworthy achievement, then it requires more theoretical and empirical endeavors in order to be better understood its benefits.

\subsection{FORGIVENESS}

Although forgiveness is a tenet addressed by important religions (KRIEGER; HANSON, 1999), it continues to be one of the least understood virtues and extremely challenging to develop, given that it presupposes a radical transformation (CAMERON; CAZA, 2002). It is theorized that forgiveness might promote positive well-being rather than merely reducing risks for negative well-being (WORTHINGTON Jr. et al., 2005). Researchers also surmise that human life would be virtually impossible without the capability of forgiveness. Following this line of reasoning, without forgiveness it would be unfeasible to cultivate relationships with friends, family members and co-workers (LENNICK; KIEL, 2005). In the context of work, it is argued that "Organizational forgiveness, then, is the capacity to foster collective abandonment of justified resentment, bitterness, and blame, and instead, it is the adoption of positive, forward-looking approaches in response to harm or damage" (CAMERON; CAZA, 2002, p. 39). Nevertheless, in more strict terms, forgiveness is usually seen as a process derived from the aftermath of a perceived harmful event (BRIGHT et al., 2008).

Overall, it is highly desirable regarding its intrinsic goodness. Forgiveness is associated with a range of benefits such as physical, mental, emotional and social health in individuals. Leaders capable of showing forgiveness impact positively their organizations (CAMERON; CAZA, 2002, p. 40). Further, the biological effects of forgiveness include physiological and psychological healing and reduced illness and stress. Additionally, it is linked to greater creativity and learning, enhanced cardiovascular fitness, emotional stability, happiness and tolerance (see BRIGHT et al., 2008, for a review). As expected, it is a crucial feature given that without allowing a tolerance for mistakes and the admittance of our imperfection, one gives rise to rigid and inflexible behavior hurting the likelihood of building 
engagement with others in ways that promote mutual good. Moreover, without engendering a climate prone to accept risk tolerance, it is likely that employees feel intimidated to recognize their mistakes or offer their feedback and, as a consequence, problems may persist (LENNICK; KIEL, 2005). Therefore, it appears that within organizations the virtue of forgiveness remains to be less common, less understood, less advocated and less valued. In fact, Bies et al. (2016) warn that even in the presence of strong meaningful workplace relationships, one cannot take for granted that forgiveness will emerge.

Forgiveness has two distinct dimensions: it is both an internal mental/emotional state and an interpersonal act. Theorists suggest that forgiveness takes place in situations where resentment, negative judgment, bitterness, and indifferent behavior are sidelined. But it is also noticed when the collective group decides to reframe an offense by adopting a positive, prosocial, learning oriented response to the violation. In doing so, the organizational members shift from past trauma and pursue an optimistic and positive future (CAMERON, 2007). Relatedly, Bright and Exline (2012) argue that forgiveness may occur at four levels, namely, intrapersonal, relational, organizational and collective-group. For his turn, Palanski (2012) proposes a model of forgiveness and reconciliation in the workplace that encompasses the collective, dyad and individual levels. It is worth pointing out the forgiveness climate posited by Fehr and Gelfand (2012), which focuses on conflicts where disagreements become personal and a victim-offender dynamic emerges. The authors suggest that forgiveness climates are most likely to occur in organizations that possess values for restorative justice, compassion, and temperance. This conceptual framework proposes that restorative justice values enable that organizations build a foundation of prosocial responses to conflict. As for compassion values, it may engender that organizations provide care and concern for others' suffering. It is argued that through temperance values, organizations build a foundation of patience and humility.

It must be emphasized that forgiveness is also distinct of forgetting. Importantly, it may vary in the form that it takes in organizations opening room for further investigations considering that it has been largely been neglected in organizational studies as compared to positive psychology (CAMERON, 2007). In this sense, it is noteworthy a revealing qualitative study conducted by Bright (2005) in a trucking company, which found basically two forms of narrative that promote forgiveness. First, the pragmatic mode, the most common, was seen as a necessary practice in order to support ongoing relationships. In such a view, the benefits outweighed the costs of not forgiving. Second, the transcendent mode saw forgiveness as a transformational practice. In other words, it is seen as a way to learn from 
and foster positive transformations in order to surpass difficulties derived from interpersonal moments. Finally, it is worth pointing out that in two experiments, Barclay and Saldanha (in press) found evidence of forgiveness in work settings, particularly when the injustice gap is addressed by means of expressive writing.

\subsection{MEANINGFUL WORK}

The POS concept embraces the construct of meaningful work as well. Broadly speaking, the positive experiences and feelings in the workplaces coalesce to generate meaningful work. Also, job satisfaction is commonly linked to meaningful work. Seen in this way, it involves considering the tasks one performs at work as intrinsically motivating and purposeful. Furthermore, it is seen as part of this equation the fellow workers as well as the goals, values and beliefs that the organization spouses. Organizational practices can create meaningfulness (i) by either improving the roles and tasks that individuals perform (ii) or enhancing the characteristics of group membership. Therefore, meaningfulness is socially constructed and, as such, it is beyond the simple function of organizational practices. Put another way, it is not only a means toward increasing performance, but it also represents an end in itself (PRATT; ASHFORTH, 2003, p. 314-315). Overall, workplaces that are designed and managed to create meaning for their workers tend to be perceived as more healthy and happy ones (GAVIN; MASON, 2004). Cameron et al. (2003, p. 365) added that "doing good along doing well, recognizing and supporting the salience of employee family and personal life, and exemplifying integrity and virtuousness in organizational policies, routines, and culture are among the belief system factors associated with meaningfulness in organizations".

To a large extent, the desire for meaning constitutes a basic human motivation (NAKAMURA; CSIKSZENTMIHALYI, 2003). But meaningful work implies the notion of work experienced as particularly significant by engendering more positive meaning for individuals. The literature review conducted by Rosso et al. (2010, p. 108-113) found that work is perceived as meaningful through seven categories of mechanisms: authenticity, selfefficacy, self-esteem, purpose, belongingness, transcendence, cultural and interpersonal sensemaking. Accordingly, authenticity connects with three sources of meaning to the enactment or development of the true self, namely, the experience of self-concordance, the identity affirmation processes, and personal engagement in work. Self-efficacy means the individuals' beliefs that they have the power and ability to produce an intended effect or, simply put, to make a difference. Self-efficacy has been employed as a mechanism of 
meaning by means of control or autonomy in the work domain, the experience of competence resulting from overcoming challenges at work and perceived impact. Self-esteem implies an individual's assessment or evaluation of his or her own self-worth. Purpose involves a sense of directedness and intentionality in life. Their review shows that it has been employed as a mechanism for the significance of work and as a value system. Belongingness enables the sense of membership, identification, and feelings of connection to social groups although work may provide individuals with meaningfulness. Belongingness has been employed as a mechanism of social identification with others at work and the more affective experience of interpersonal connectedness. Meanwhile, transcendence helps connect or supersede the ego toward an entity greater than the self or beyond the material world. It is activated by both interconnection and the experience of self-abnegation. Finally, the cultural and interpersonal sensemaking involves the production of meaning rather than meaningfulness. In other words, the previous mechanisms are linked to how meaningful work is because of its alignment with features of the self or others, whereas the cultural and interpersonal sensemaking capabilities seek to understand how different types of work meaning are constructed. Overall, meaningful work construct has been received little examination under POS concept, yet other related constructs have been under POS researcher's scrutiny such as calling (e.g., WRZESNIEWSKI et al., 2003; WRZESNIEWSKI, 2012) and job crafting (e.g., BERG et al., 2010; BERG et al., 2013).

\subsection{POSITIVE DEVIANCE}

By and large, deviance has been labeled as a by-product of aberration or some kind of unacceptable behavior. By contrast, positive deviance is regarded as a form of virtuousness inspired by some of humanity's highest aspirations. More specifically, it is defined "as intentional behaviors that depart from the norms of a referent group in honorable ways" (SPREITZER; SONENSHEIN, 2003, p. 209). This definition takes into account behaviors with honorable intentions, independent of outcome, given that positive intentions do not necessarily reach positive outcomes (SPREITZER; SONENSHEIN, 2004). It involves people behaving in ways that depart from expected norms toward a direction that some group judge positive (LAVINE, 2012). Taken together, it is associated with excellent effectiveness, extraordinary efficiency, perfect quality, benevolent ethics, honoring relationships, and flourishing adaptation (CAMERON, 2003). Extraordinary organizations exhibit positive deviance on the human dimension, that is, they usually engender virtuousness in relationships 
and in the treatment of people. As a result, it is noticed when organizations have to downsize and use to do so in a caring and compassionate manner (CAMERON; CAZA, 2002).

Positive deviants are somehow motivated to serve others rather than achieving personal glory. People who show such feature are prone to experience greater subjective well-being. It is expected that the relationship between the positive deviant and the recipient of the deviant behavior be strengthened on the grounds of the positively deviant behavior. To some degree, it propels that individuals take risks for positive change and thus the acts of positive deviance inside organizations can become extraordinarily positive (SPREITZER; SONENSHEIN, 2003). Illustrative of this reasoning, Warren (2003) posited that "Behavior that deviates from the reference group norms but conforms to hypernorms is constructive deviance. In a business organization this behavior includes certain types of whistle-blowing" (p. 628, italics in the original). By contrast, when individuals break the ethical rules established within an organization, it is named as workplace deviance (SIMS, 2010). To Quinn and Wellman (2012), positive deviance can help management introduce new ideas and provide valid arguments aiming at positive change by focusing on magnifying positive deviance rather than eliminating negative. In a related vein, theorists suggest the construct of constructive deviance embraces several different behaviors such as including taking charge, creative performance, expressing voice, whistle-blowing, extra-role behaviors, prosocial behaviors, prosocial rule breaking, counter-role behaviors, and issue selling. The antecedents of their conceptual model cover job-focused perceptions, supervisor-focused characteristics, group-focused characteristics, organization-focused characteristics and employee characteristics mediated by intrinsic motivation, felt obligation, and psychological empowerment (VADERA et al., 2013). With this in mind, it is astonishing that such promising vein of research has provided only scarce empirical evidence until now. In this regard, honorable initiatives must be attributed to the case study of Green Mountain Coffee Roasters, an example of positive deviation along the ethical continuum leading to a conscious capitalism (NEVILLE, 2008), and the investigation of the past environmental experience of a board playing a critical role in allowing organizations to deviate positively in their environmental practices (WALLS; HOFFMAN, 2013).

\subsection{POSITIVE EMOTIONS}

Positive emotions have been investigated by many sub-areas of management studies and psychology. As a result, one can claim that it is a germane topic regarding that 
emotions permeate human life. It is recognized that people who feel good usually live longer. Positive emotions can be conducive to both states of mind and behavior that indirectly enable an individual to face hard times. It is proposed that "positive emotions can trigger upward spirals that transform communities into more cohesive, moral and harmonious social organizations" (FREDRICKSON, 2003b, p. 335). Similarly, Cameron (2003) suggests that positive emotions (for example, compassion, optimism, and joy, among others) may lead to positive activities in organizations such as helping behaviors, truth-telling and altruism, which trigger in turn spirals of positive feelings. Positive emotions may help individuals to become more resilient, socially integrated, and capable. Fundamentally, positive emotions help people to survive and thrive (FREDRICKSON, 2003a). Taken together, positive emotions, positive energy, and positive human connections can engender meaningful experience and extraordinary performance (CAMERON et al., 2003).

Individuals who regularly experience positive emotions tend to grow toward optimal functioning. Positive emotions are also associated with beneficial outcomes because they broad individual's habitual modes of thinking and action (FREDRICKSON, 2004; 2005; WRIGHT; CROPANZANO, 2004). Some examples of positive emotions are joy, hope, relief, admiration, pride, and love (ROBERTS, 2004), but it also includes optimism, patience, gratitude and so on. Moreover, "positive emotions produce the tendency to approach rather than to avoid and to prepare the individual to seek out and undertake new goals" (LYUBOMIRSKY et al., 2005, p. 804). When coupled with collaborative values it may lead an organization to thrive, given that its members are motivated to create new organizational procedures that may benefit both the individuals and their organizations. Positive motions along with the expansion of relational capacities may be boundless. Experiencing positive emotions can add value to organizations, especially by contributing to their improved functioning and performance (SEKERKA; FREDRICKSON, 2007). It is advocated that "The experience of positive emotions can help individuals transform themselves to become more creative, connected, resilient, and ultimately healthy individuals" (SIMMONS; NELSON, 2007, p. 49). By contrast, it seems that negative emotions may narrow an individual's momentary thought-action repertoire. Researchers propose that positive organizational emotional climate may contribute to increases in organizational identification and in organizational relational strength (SEKERKA; FREDRICKSON, 2008). Fortunately, there is the tendency that human beings adopt the positive mindset through their thoughts, judgments, emotions and language (CAMERON, 2008). As wisely noted by Sekerka et al. (2012, p. 175), "understanding what creates an effective and sustainable workplace is nearly 
impossible without considering the influence of emotions". Unlike negative tendencies and responses, the benefits linked to positive emotions have received less scholarly attention (SEKERKA; FREDRICKSON, 2007), particularly from POS scholars.

\subsection{RESILIENCE}

Resilience construct has been addressed by both POS concept and by positive organizational behavior (POB) scholars. In this regard, Sutcliffe and Vogus (2003) argue that a resilience perspective offers insights about organizational adjustment and adaptation, especially in a world where people and organizations must handle increasingly complex and chaotic environments commonly fostered by hypercompetition and rapid change. On the other hand, Luthans (2002, p. 702) defines resiliency as "the positive psychological capacity to rebound, to 'bounce back' from adversity, uncertainty, conflict, failure or even positive change, progress and increased responsibility". Positive human functioning is most remarkable in contexts of significant life challenge and adversity. In other words, when individuals are being tested much about their strengths are indeed identified (RYFF; SINGER, 2003).

POS theorists suggest that organizational resilience derives from organizational processes aimed at enhancing an organization's overall competence and growth (under this understanding, therefore, the ability to learn and fundamentally to learn from mistakes are judged as essential steps) and restoring efficacy (i.e. ,enhancing the ability to quickly process feedback and flexibly rearrange or transfer knowledge and resources) in order to deal with situations that emerge (SUTCLIFFE; VOGUS, 2003). Other authors posit that the resilience in the workplace are intertwined with the practice of caring relationships, that is, an approach that facilitates to focus on human development (e.g., WILSON; FERCH, 2005). To put it in a simpler terms, resilience, adaption and hardiness are attributes of organizations and suitable to cope with major trauma or damage resulting from external or uncontrollable events (as opposed to making mistakes and human error) (POWLEY; CAMERON, 2006). Resiliency is related to three factors, namely, assets, risks, and adaptation processes. Assets encompass a set of aspects such as knowledge, skills, abilities, social relationships and material resources that can improve the likelihood of success and adaptation despite setbacks. Risk factors involve adversities such as unemployment, divorce, loss of loved ones, physical illness and the lack of essential assets. Adaptational processes refer to coping, stress management, problem solving, and goal setting strategies (YOUSSEF; LUTHANS, 2005). Organizational 
resilience is conceptualized as the outcome of a set of convergent organizational capacities, namely, perceptual stance, contextual integrity, strategic capacity, and strategic acting. This model proposes that by building organizational resilience an organization may reach organizational evolvability capability, i.e. recovery, adaptation/continuity and renewal conditions (KANTUR; ISERI-SAY, 2012).

Pertinent literature indicates that resilient individuals exhibit more positive emotions than do their less resilient peers even in response to stressful circumstances (FREDRICKSON, 2005). Thus, at the least on the individual level, "How to cope and utilize positive behavioral patterns under stress constitutes the idea of resilience" (LOPEZ et al., 2005, p. 706). When combined with hope, resilient employees get to bounce back and beyond, they also show self-efficacy skills toward overcoming a significant challenge and optimism to repeat in the future (LUTHANS et al., 2007). The creation of a resilient organization cannot avoid a strategy to stop stress and improve the mental well-being of people at work (MOWBRAY, 2008). It is taken for granted that "More than ever, the development of resilience is needed to help individuals recover from adversity or personal setbacks - not if they happen, but when they happen" (AVEY et al., 2009, p. 682, italics in the original).

POB scholars have provided a positive link between resilience and employee performance, job satisfaction, organizational commitment, and work happiness (see AVEY et al., 2009, for a review of these empirical investigations). But findings also showed that adequate financial reserves and positive relationships (relational reserves) predicted organizational resilience at Southwest (GITTELL et al., 2006). In effect, resilience is undeniably much needed in today's business environment (CAZA; MILTON, 2012). Nonetheless, resilience interventions are regarded as newer at the workplace and, accordingly, we need more research to assess their outcomes (OLLIER-MALATERRE, 2010). To a large extent, little attention has been given to how people develop resiliency in themselves or others (LUTHANS et al., 2006). It is noteworthy two recent reviews that shed more light into this topic, yet the authors are not POS researchers. For instance, Kossek and Perrigino (2016) suggest that resilience is individually and occupationally related to a multilevel system. Rather, occupational resilience embraces a set of features such as (a) multiple conceptual strands (trait, capacity, and processes); (b) distinct occupational positive and negative triggers; (c) different resilience types (i.e., cognitive, emotional, and physical) that vary in many dimensions across occupations; (e) a dynamic phenomenon that takes place within and across career stages; (e) both content-general, and job-specific occupational 
tensions; and (f) work and nonwork domains. In turn, Linnenluecke's (2017) work identifies that the concept of resilience is linked with five research streams, namely: (a) organizational responses to external threats; (b) organizational reliability; (c) employee strengths; (d) the adaptability of business models; or (e) design principles that reduce supply chain vulnerabilities and disruptions. Overall, this review found some evidence that resilience construct has gained attention from POB scholars than POS researchers.

\subsection{THRIVING}

Another construct of growing interest for researchers is thriving. It is a genuine aspiration to enjoy a thriving life and work toward attaining it. According to Spreitzer et al. (2005), when people are thriving they tend to feel progress as the result of both a sense of learning (i.e., greater understanding and knowledge) and a sense of vitality (aliveness). In essence, it denotes a subjective experience whereby individuals evaluate whether what they are doing and how they are doing and if it is helping them somehow to develop. In other words, it helps individuals to navigate and change their work contexts whenever it is necessary to promote their own development.

Importantly, "the experience of thriving at work also promotes more agentic behaviors as individuals seek to sustain their own thriving into the future" (SPREITZER et al., 2005, p. 540). Thus, it is unlikely to thrive at work without active and intentional engagement in the process of personal growth. Hence, it is argued that thriving is linked to important individual and organizational outcomes. However, the process of thriving extensively at work can damage the possibility of thriving in home life likewise. Theorists note that the interest in thriving lies at "both growth in social trends recognizing that employee well-being and health include positive aspects that transcend economic productivity" (SPREITZER; SUTCLIFFE, 2007, p. 83). Research shows that employees just one standard deviation above the mean performed more than $16 \%$ better than those one standard deviation below the mean. In addition, findings revealed important organizational outcomes such as they were $32 \%$ more committed to the organization, $46 \%$ more satisfied with their job and $125 \%$ less burned out. Results also showed that across all samples, whether professional, nonprofessional, for profit or not for profit, thriving employees were highly satisfied with their jobs. Further, they tend to be healthier, reporting fewer physical or somatic complaints, far fewer doctor visits and less burnout or strain, which may be translated into likely reduced health care costs. Overall, they also missed $74 \%$ less days of 
work. Thriving is also relevant for leaders' effectiveness. In a study of executives across different industries (SPREITZER et al., 2012), thriving leaders were rated 17\% higher by their subordinates than leaders who reported lower levels of thriving. When experienced simultaneously, the learning and vitality components of thriving help sustain performance. Taken together, those who showed high scores on both learning and vitality had performance assessments that were 12\% higher (as rated by their bosses) than those who had high scores on either learning or vitality, but not both. Thus, to improve their thriving, individuals seek ways to craft their work to be more meaningful and impactful. Findings suggest that organizations can increase the potential for employees to thrive when they: (a) enable decision-making discretion; (b) provide information about the organization and its strategy; (c) minimize incivility; (d) provide performance feedback; and (e) create a climate that promotes diversity. In other study that focused on four of these factors, thriving across the six organizations investigated increased 42\% (SPREITZER et al., 2012).

Furthermore, three studies found support for the two-dimensional conceptualization of thriving, in addition to suggesting that thriving contributes to human sustainability through psychological (reduced burnout) and physical (perceptions of health) well-being (PORATH, 2012). Another investigation found that task focus and exploration mediate the relationship between positive meaning and vitality. More specifically, data showed that resources such as positive meaning were related to agentic work behaviors (i.e., task focus and exploration), which in turn were positively related to vitality and learning at work (NIESSEN et al., 2012). At last, work by Paterson et al. (2014) found a positive relationship between thriving at work and supervisor-rated employee self-development at work $(\beta=.27, \mathrm{p}<.01)$ and thriving and performance $(\beta=.28, \mathrm{p}<.01)$. This research model also tested successfully agentic work behaviors (task focus and heedful relating) and two new antecedent variables (PsyCap and supervisor support climate). In sum, it is worth emphasizing that "employees seek something more - they want a job situation that enables them to thrive. They want work that doesn't require substantial recovery in the evening after work, on weekends or vacations. Instead, work can be a place where people feel alive and vital, where they can grow and get better every day. Today's organizations can and must do better" (SPREITZER et al., 2012, p.161, emphasis added).

\subsection{Virtuous aspects}


Virtuousness is treated as a key component of POS concept. Indeed, it is certainly the most investigated topic of POS through quantitative designs. It is derived from the Latin word virtus, meaning 'strength' or 'excellence'. To Plato and Aristotle virtuousness meant the desires and actions that produce personal and social good (CAMERON, 2003). Virtue represents a state of character, which in turn inspires one's choices (ARISTOTLE cited in CAZA et al., 2005). It presupposes the practice of good habits that lead to excellence in personal character (EMMONS; SHELTON, 2005). Thus, "When encountered, virtuousness is highly prized and admired, and virtuous individuals are almost universally revered, emulated, and even sainted" (CAMERON, 2003, p. 48). However, it is notorious that our planet is in great need forhwen encountered virtuous organizations in order to preserve our natural resources, climate and to provide healthy work environments just to mention a few challenges. Virtuous organizations usually exhibit attributes and behaviors that go beyond a consistent moral or ethical code. Virtuousness is highly desirable within organizations given that by observing it one may enable a self-reinforcing upward spiral toward positive deviance (CAMERON; CAZA, 2002). To a large extent, virtuousness guides actions toward human fulfillment and social betterment, characterized by ennobling human behaviors. It is seen as an inoculation agent against negative occurrences in organizations (CAMERON et al., 2003). Virtuousness can be manifested in and through organizations as single individuals' activities or as collective action. Taken together, the features of an organization's culture or the extant processes may enable or disable virtuous deeds (CAMERON, 2003; WRIGHT; GOODSTEIN, 2007). Therefore, it is important to keep in mind that "Organizational-level virtues serve the moral of goals of an organization and not simply its bottom line, whether this be profit, power, or persistence" (PARK; PETERSON, 2003, p. 37). Importantly, Rambur et al. (2010) argue that virtuous organization must engender an evolving social and economic environment. Taken as a whole, virtues have become a theme of serious examination among organizational researchers and obviously progressive companies concerned with creating new, more holistic, healthy, and humane workplaces (MANZ et al., 2008).

Research provides support to the proposition that virtuousness of organizations actions (i.e., humane and courageous organizational actions) inspire members' responses that lead to organizational identification and attachment. Evidence indicated that members used virtue frames to interpret organizational actions and these interpretations affected their emotions, the way they interpreted themselves and their images of the organization (RHEE et al., 2005). Thus, organizational-level virtues, i.e., the features of the organization, contribute 
to the fulfillment of its members (PARK; PETERSON, 2003). Nevertheless, it appears that virtuousness does not permeate the business world as it should. As a result, "Words such as virtue hope, and honor are not typically associated with the modern competitive environment" (CAZA et al., 2004, p. 173). Nevertheless, it is perceived that virtue adherent behavior impacts positively organizations in many aspects, including by both an amplifying effect and a buffering effect (see CAZA et al., 2004, for a review). But it may be also particularly powerful in times of change and ambiguity (CAZA et al., 2005). Organizational virtuousness is positively and significantly related to organizational performance (i.e. innovation, quality, turnover and customer retention). Further, there is a significant relationship between perceived virtuousness and organizational profitability (CAMERON et al., 2004).

Other study found support to the relationships between five virtues (optimism, trust, compassion, integrity, and forgiveness) and five outcomes measured (profit, innovation, quality, employee turnover, and customer retention). More specifically, integrity, trust and optimism showed the strongest and most frequent associations with performance outcomes (CAMERON et al., 2008). It is also argued that feelings of elevation, inspiration and joy are associated with demonstrations of virtuousness. Individual virtuousness helps shape organizational virtuousness (CAMERON et al., 2004). Researchers suggest that the perceptions of organizational virtuousness predict affective commitment either directly or through the mediating role of happiness (REGO et al., 2011). Finally, it is worth standing out that the cultivation of virtuousness evokes the best of the human condition or the highest aspirations human beings search for. In this regard, organizational virtuousness is often manifested by means of collective displays of moral excellence (CAMERON; WINN, 2012, p. 231). Overall, POS researchers have elucidated the advantages and positive outcomes derived from the presence of virtuousness within companies.

\section{CONCLUSIONS AND FUTURE STUDIES}

This literature review found evidence that POS concept has some theoretical convergence with other disciplines, particularly workplace spirituality, POB and positive psychology (VASCONCELOS, 2008, 2015; see also LAVINE et al., 2014, for a broad analysis of the possibilities between POS and management spirituality and religion). All these disciplines provide a positive approach in management studies, yet each of them explores some particularities of it. For example, at the core of POS and POB resides the contribution 
of psychology positive findings (see Figure 1).

Figure 1 - Theoretical intersections

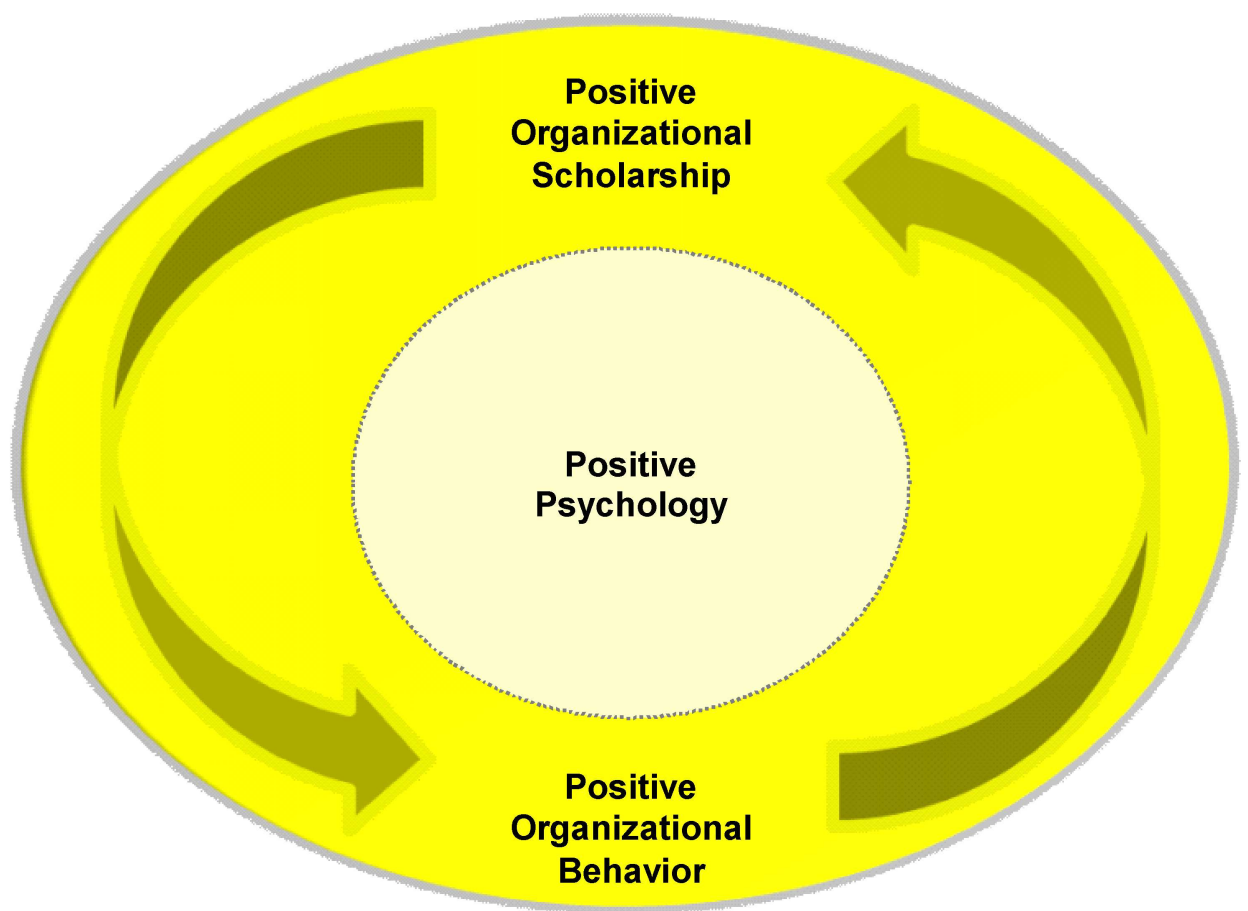

Source: designed by the author.

In order to clarify the domains of each discipline, some authors argue that POS focuses more on the macro-levels by means of the lens of institutional theories, network models and resource-based view of the firm. Whereas POB is dedicated to exploring the positive individual-level states (PsyCap: confidence, hope, optimism, and resiliency) and their development (DUTTON et al., 2005; LUTHANS et al., 2007). Therefore, POS appears to have more ambitious goals than $\mathrm{POB}$, yet $\mathrm{POB}$ findings have offered compelling evidences.

In addition, this review provides evidence that some constructs attributed to POS requires intense investigation to identify more robust findings (see Table 1 for a synthesis). Considering it, I am fully aligned with Hackman (2009) when he states that POS needs more careful attention to the constructs validity of its central concepts. On the other hand, I surmise that other constructs may be also explored under POS perspective such as care, empathy, friendship, gratitude, kindness and patience. Overall, they represent human strengths that are highly required to deal with the harsh contemporaneous corporate life. Similarly, it will be very relevant to examine how some organizations get to enchant their 
employees, while others make exactly the contrary. In other words, I presume that it would be useful to indentify how organization members feel or feel not enchanted by their employers. As a consequence, one would know even more about good workplaces (implicit goal of POS).

Table 1 - Synthesis of the literature review

\begin{tabular}{|l|c|c|c|}
\hline Construct & Driver & $\begin{array}{c}\text { Approaches } \\
\text { Under POS } \\
\text { Lens }\end{array}$ & $\begin{array}{c}\text { Level of } \\
\text { Theoretical } \\
\text { Development }\end{array}$ \\
\hline Compassion & Other-focused & Qualitative & High \\
\hline $\begin{array}{l}\text { Connections \& } \\
\text { Relationships }\end{array}$ & Other-focused & Quantitative & Medium \\
\hline Cooperation & Inner and other-focused & Conceptual & High \\
\hline Courageous & Inner-focused & $\begin{array}{c}\text { Qualitative } \\
\&\end{array}$ & Medium \\
\hline Flourishing & Inner and other-focused & Conceptual & Low \\
\hline Forgiveness & Inner and other-focused & Qualitative & Medium \\
\hline Meaningful Work & Inner and other-focused & Conceptual & Medium \\
\hline Positive Deviance & Other-focused & Qualitative & Low \\
& & \& & \\
\hline Positive Emotions & Inner-focused & Conceptual & Low \\
\hline Resilience & Inner-focused & Conceptual & Low \\
\hline Thriving & Inner-focused & Quantitative & Medium \\
\hline Virtuous & Inner-focused & Quantitative & High \\
\hline
\end{tabular}

Another groundbreaking POS book - The Oxford Handbook of Positive Organizational Scholarship (CAMERON; SPREITZER, 2012) -, depicts a set of constructs that began to be theoretically addressed by POS lens. More specifically, authors wrote about psychological capital, prosocial motivation, callings, work engagement, proactivity, creativity, curiosity, positive traits, neuroscience, positive energy, positive emotions, subjective well-being, passion, emotional intelligence, group emotions, virtuousness, forgiveness, humility, compassion, hope, courage, justice, integrity, positive ethics, strengths, 
character, connections, relational coordination, reciprocity, intimacy, civility, trust, trustworthiness, humor, psychological safety, career development, mentoring, socialization, diversity, communication, negotiation, work-family dynamics, symbolism, resourcefulness, collective efficacy, design at jobs, mindful organizing, organizational identity, innovation, organizational boundaries, organizational development, appreciative inquiry, positive change, implementing positive change, authentic leadership, leadership development, organizational sustainability, strategic change, positive strategy, managing the unexpected, organizational healing, recovery, responding to crisis, resilience, posttraumatic growth, psychological ambivalence, stress interventions, positive deviance linked with sustainability, critical theory, economic models, social movements, spirituality, positive deviance, and international peacemaking. Obviously, some of these constructs listed above are more promising than others.

On the basis of it, this review contributes to POS concept by closely examining some of its major constructs (fundamentally those that are more theoretically and empirically developed) such as compassion, connections and relationships, cooperation, courageous, flourishing, forgiveness, meaningful work, positive deviance, positive motions, resilience, thriving, and virtuous aspects. The results reveal a richer understanding about their benefits and challenges, as well as emphasizing new possibilities for future studies. Despite the difficulties and problems discussed here (e.g., few empirical work, validity issues, and some theoretical intersections) under the relatively new POS concept has ever gathered germane knowledge that has helped to explain how organizations improve their dynamics and general outcomes by adopting more constructive approaches, as well as providing new theoretical avenues for researchers to peruse. On the other hand, it is exciting to find that POS researchers - taking into account that POS is only in the early stages of theoretical development - have worked with a sizeable number of constructs, topics and ideas. Although researchers have to go deep in many of them through more profound research and refined theoretical conceptualizations, it is also clear that the potential of POS concept is extremely favorable.

\section{REFERENCES}

AVEY, J.B.; LUTHANS, F.; JENSEN, S.M. Psychological capital: a positive resource for combating employee stress and turnover. Human Resource Management, v. 48, n. 5, p. 677-693, 2009. 
BARCLAY, L.J.; SALDANHA, M.F. Facilitating forgiveness in organizational contexts: exploring the injustice gap, emotions, and expressive writing interventions. Journal of Business Ethics, in press.

BERG, J.; DUTTON, J.E.; WRZESNIEWSKI, A. Job crafting and meaningful work. In: DIK, B.J.; BYRNE, Z.S; STEGER, M.F. (Eds.). Purpose and meaning in the workplace. Washington: APA Books, 2013.p. 81-104.

BERG, J.M.; WRZESNIEWSKI, A.; DUTTON, J.E. Perceiving and responding to challenges in job crafting at different ranks: when proactivity requires adaptivity. Journal of Organizational Behavior, v. 31, n. 2-3, p. 158-186, 2010.

BIES, R.J.; BARCLAY, L.J.; TRIPP, T.M.; AQUINO, K. A systems perspective on forgiveness in organizations. Academy of Management Annals, v. 10, n. 1, p. 245-318, 2016.

BLATT, R.; CAMDEN, C.T. Positive relationships and cultivating community. In:

DUTTON, J.E.; RAGINS, B.R. (Eds.). Exploring positive relationships at work: Building a theoretical and research foundation. Mahwah: Lawrence Erlbaum Associate, 2007. p. 243264.

BONO, J.E.; DAVIES, S.E.; RASCH, R.L. Some traits associated with flourishing at work. In: CAMERON, K.S.; SPREITZER, G.M. (Eds.). The Oxford Handbook of Positive Organizational Scholarship. New York: Oxford University Press, 2012. p. 125-137. BOYATZIS, R.E.; SMITH, M.L.; BLAIZE, N. Developing sustainable leaders through coaching and compassion. Academy of Management Learning \& Education, v. 5, n. 1, p. 8-24, 2006.

BRIGHT, D.S. Forgiveness and change: begrudging, pragmatic, and transcendent responses to discomfiture in a unionized trucking company. Doctoral dissertation, Case Western Reserve University, Cleveland, 2005.

BRIGHT, D.S.; EXLINE, J.J. Forgiveness at four levels: intrapersonal, relational, organizational and collective-group. In: CAMERON, K.S.; SPREITZER, G.M. (Eds.). The Oxford Handbook of Positive Organizational Scholarship. New York: Oxford University Press, 2012. p. 244-259.

BRIGHT, D.S.; FRY, R.E.; COOPERRIDER, D.L. Forgiveness from the perspectives of three response modes: begrudgement, pragmatism, and transcendence. In: MANZ, C.C.; CAMERON, K.S.; MANZ, K.P.; MARX, R.D. (Eds.). The virtuous organization: insights from some of the world's leading management thinkers. Hackensack: World Scientific Publishing, 2008. p. 67-95. 
BRUELLER, D.; CARMELI, A. Linking capacities of high-quality relationships to team learning and performance in service organizations. Human Resource Management, v. 50, n. 4, p. 455-477, 2011.

CAILLIER, J.G. The impact of high-quality workplace relationships in public organizations. Public Administration, (forthcoming).

CAMERON, K.; CAZA, A.; BRIGHT, D. Positive deviance, organizational virtuousness, and performance. Working paper, University of Michigan - Ross School of Business, 2008. CAMERON, K.; MCNAUGHTAN, J. Positive organizational change. The Journal of Applied Behavioral Science, v. 50, n. 4, p. 445-462, 2014.

CAMERON, K.; MORA, C.; LEUTSCHER, T.; CALARCO, M. Effects of positive practices on organizational effectiveness. The Journal of Applied Behavioral Science, v. 47, n. 3, p. 266-308, 2011.

CAMERON, K.S. ORGANIZATIONAL VIRTUOUSNESS AND PERFORMANCE. In: CAMERON, K.S.; DUTTON, J. E.; QUINN, R.E. (Eds.). Positive Organizational Scholarship. San Francisco: Berrett-Koelher, 2003. p. 48-6.

CAMERON, K.S. Organizational effectiveness: its demise and re-emergence through positive organizational scholarship. Working Paper, University of Michigan - Ross School of Business, 2005.

CAMERON, K.S. Forgiveness in organizations. In: D.L. NELSON, D. L.; COOPER, C. L. (Eds.). Positive organizational behavior. London: Sage, 2007. p. 129-142.

CAMERON, K.S. Paradox in Positive Organizational Change. Journal of Applied Behavioral Science, v. 44, n. 1, p.7-24, 2008.

CAMERON, K.S.; BRIGHT, D.; CAZA, A. Exploring the relationships between organizational virtuousness and performance. American Behavioral Scientist, v. 47, n. 6, p. 766-790, 2004.

CAMERON, K.S.; CAZA, A. Organizational and leadership virtues and the role of forgiveness. Journal of Leadership \& Organizational Studies, v. 9, n. 1, p. 33-48, 2002. CAMERON, K.S.; CAZA, A. Contributions to the discipline of Positive Organizational Scholarship. American Behavioral Scientist, v. 47, n. 6, p. 731-739, 2004. CAMERON, K.S.; DUTTON, J.E.; QUINN, R.E. (Eds.). Positive organizational scholarship. San Francisco: Berrett-Koelher, 2003. CAMERON, K.S.; SPREITZER, G.M. (Eds.). The Oxford handbook of positive organizational scholarship. New York, NY: Oxford University Press, 2012. 
CAMERON, K.S.; WINN, B. Virtuousness in organizations. In: CAMERON, K.S.; SPREITZER, G.M. (Eds.). The Oxford Handbook of Positive Organizational

Scholarship. New York: Oxford University Press, 2012. p. 231-243.

CARMELI, A.; BRUELLER, D.; DUTTON, J.E. Learning behaviours in the workplace: the role of high-quality interpersonal relationships and psychological safety. Systems Research and Behavioral Science, v. 26, n. 1, p. 81-98, 2009.

CARMELI, A.; FRIEDMAN, Y.; TISHLER, A. Cultivating a resilient top management team: the importance of relational connections and strategic decision comprehensiveness. Safety Science, v. 51, n. 1, p. 148-159, 2013.

CARMELI, A.; GITTELL, J.H. High quality relationships, psychological safety and learning from failures in work organizations. Journal of Organizational Behavior, v. 30, n. 6, p. 709-729, 2009.

CASSELL, E.J. Compassion. In: SNYDER, C.R.; LOPEZ, S. J. (Eds.). Handbook of Positive Psychology. New York, NY: Oxford University Press, 2005. p. 434-44. CAZA, A.; BARKER, B.A.; CAMERON, K.S. Ethics and ethos: the buffering and amplifying effects of ethical behavior and virtuousness. Journal of Business Ethics, v. 52, n. 2, p. 169-178, 2004.

CAZA, A.; BARKER, B.A.; CAMERON, K.S. Virtues and ethics: values in the organizations. Working paper, University of Michigan - Ross School of Business, 2005. CAZA, B.B.; CAZA, A. Positive organizational scholarship: a critical theory perspective. Journal of Management Inquiry, v. 17, n. 1, p. 21-33, 2008.

CAZA, B.B.; MILTON, L.P. Resilience at work: building capability in the face of adversity. In: CAMERON, K.S.; SPREITZER, G.M. (Eds.). The Oxford handbook of positive organizational scholarship. New York: Oxford University Press, 2012. p. 895-908. DUTTON, J.E. Breathing life into organizational studies. Journal of Management Inquiry, v. 12 , n. 1, p. 5-19, 2003a.

DUTTON, J.E. Energize your workplace: how to create and sustain high-quality connections at work. San Francisco: Jossey-Bass, 2003b.

DUTTON, J.E.; GLYNN, M.A.; SPREITZER, G. Positive organizational scholarship. Working paper, University of Michigan - Ross School of Business, 2005.

DUTTON, J.E.; HEAPHY, E.D. The power of high-quality connections. In: CAMERON, K.S.; DUTTON, J. E.; QUINN, R.E. (Eds.). Positive organizational scholarship. San Francisco: Berrett-Koelher, 2003. p. 263-278. 
DUTTON, J.E.; LILIUS, J.; KANOV, J. The transformative potential of compassion at work. In: PIDERIT, S.K.; FRY, R.E.; COOPERRIDER, D.L. (Eds.). Handbook of transformative cooperation. Stanford: Stanford University Press, 2007. p. 107-126.

DUTTON, J.E.; WORLINE, M.C.; FROST, P.J.; LILIUS, J. Explaining compassion organizing. Administrative Science Quarterly, v. 51, n. 1, p. 59-96, 2006.

EMMONS, R.A.; SHELTON, C.M. Gratitude and the science of positive psychology. In:

SNYDER, C.R.; LOPEZ, S. J. (Eds.). Handbook of Positive Psychology. New York, NY: Oxford University Press, 2005. p. 459-471.

FEHR, R.; GELFAND, M.J. The forgiving organization: a multilevel model of forgiveness at work. Academy of Management Review, v. 37, n. 4, p. 664-688, 2012.

FINEMAN, S. On being positive: concerns and counterpoints. Academy of Management Review, v. 31, n. 2, p. 270-291, 2006.

FLYNN, F.J. How much is it worth to you? Subjective evaluations of help in organizations?

Research in Organizational Behavior, v. 27, p. 133-174, 2006.

FREDRICKSON, B.L. Positive emotions and upwards spirals in organizations. In:

CAMERON, K.S.; DUTTON, J. E.; QUINN, R.E. (Eds.). Positive Organizational

Scholarship. San Francisco: Berrett-Koelher, 2003. p. 163-175.

FREDRICKSON, B.L. The value of positive emotions. American Scientist, v. 91, n. 4, p. 330-335, 2003b.

FREDRICKSON, B.L. Gratitude, like other positive emotions, broadens and builds. In: R.A. EMMONS; MCCULLOUGH, M.E. (Eds.). The psychology of gratitude. New York:

Oxford University Press, 2004. p. 145-166.

FREDRICKSON, B.L. Positive emotions. In: SNYDER, C.R.; LOPEZ, S. J. (Eds.).

Handbook of Positive Psychology. New York, NY: Oxford University Press, 2005. p. 120134.

FREDRICKSON, B.L. Positivity: groundbreaking research reveals how to embrace the hidden strength of positive emotions, overcome negativity, and thrive. New York, NY: Crown Publishers, 2009.

FROST, P.J. Why compassion counts! Journal of Management Inquiry, v. 8, n .2, p. 127$133,1999$.

FROST, P.J.; DUTTON, J.E.; MAITLIS, S.; LILIUS, J.M.; KANOV, J.M.; WORLINE, M.C. Seeing organizations differently: three lenses on compassion. In:

Clegg, S. R; Hardy, C.; Lawrence, T. B.; Nord W.R. (Eds.) The Sage Handbook of Organization Studies, 2nd edition. London: Sage Publications, 2006a. p. 843-866. 
FROST, P.J.; DUTTON, J.E.; WORLINE, M.C.; WILSON, A. Narratives of compassion in organizations. In: FINEMAN (Ed.). Emotions in organizations, 2nd edition. London: Sage Publications, 2006b. p. 25-45.

GAVIN, J.H.; MASON, R.O. The virtuous organizations: the value of happiness in the workplace. Organizational Dynamics, v. 33, n. 4, p. 379-392, 2004.

GEORGE, J.M. Compassion and capitalism: implications for organizational studies. Journal of Management, v. 40, n. 1, p. 5-15, 2014.

GHOSHAL, S. Bad management theories and are destroying good management practices.

Academy of Management Learning \& Education, v. 4, n. 1, p. 75-91, 2005.

GITTELL, J.H.; CAMERON, K.; LIM, S.; RIVAS, V. Relationships, layoffs and organizational resilience: airline industry responses to September 11. The Journal of Applied Behavioral Science, v. 42, n. 3, p. 300-329, 2006.

GOLDEN-BIDDLE, K.; GERMANN, K.; REAY, T.; PROCYSHEN, G. Creating and sustaining positive organizational relationships: a cultural perspective. In: DUTTON J.E.; RAGINS, B.R. (Eds.). Exploring positive relationships at work: Building a theoretical and research foundation. Mahwah, NJ: Lawrence Erlbaum Associate, 2007. p. 289-305

HACKMAN, J.R. The perils of positivity. Journal of Organizational Behavior, v. 30, n. 2, p. 309-319, 2009.

HARBOUR, M.; KISFALVI, V. In the eye of the beholder: an exploration of managerial courage. Journal of Business Ethics, v. 119, n. 4, p. 493-515, 2014.

HILL, R.P.; STEPHENS, D.L. The compassionate organization in the 21 st Century.

Organizational Dynamics, v. 32, n. 4, p. 331-341, 2003.

KANOV, J.M.; MAITLIS, S.; WORLINE, M.C.; DUTTON, J.E.; FROST, P.J; LILIUS, J.M. Compassion in organizational life. American Behavioral Scientist, v. 47, n. 6, p. 808-827, 2004.

KANTUR, D.; ISERI-SAY, A. Organizational resilience: a conceptual integrative framework. Journal of Management \& Organization, v. 18, n. 6, p. 762-773, 2012. KARAKAS, F.; SARIGOLLU, E. The role of leadership in creating virtuous and compassionate organizations: narratives of benevolent leadership in an Anatolian Tiger.

Journal of Business Ethics, v. 113, n. 4, p. 663-678, 2012.

KOERNER, M.M. Courage as identity work: accounts of workplace courage. Academy of Management Journal, v. 57, n. 1, p. 63-93, 2014.

KOSSEK, E.E.; PERRIGNO, M.B. Resilience: a review using a grounded integrated occupational approach. The Academy of Management Annals, v. 10, n.1, p. 729-797, 2016. 
KRAHNKE, K.; COOPERRIDER, D. Appreciative inquiry: inquiring new questions and dreaming new dreams. In: Biberman, J.; Tischler, L. (Eds.). Spirituality in business: theory, practice, and future directions. New York, NY, Palgrave Macmillan, 2008. p. 17-34.

KRIEGER, M.P.; HANSON, B.J. A value-based paradigm for creating truly healthy organizations. Journal of Organizational Change Management, v. 12, no. 4, p. 302-317, 1999.

LAVINE, M. Positive deviance: a metaphor and method for learning from the uncommon. In K.S. In: CAMERON, K.S.; SPREITZER, G.M. (Eds.). The Oxford handbook of positive organizational scholarship. New York: Oxford University Press, 2012. p. 1014-1026. LAVINE, M.; BRIGHT, D.; POWLEY, E.H.; CAMERON, K.S. Exploring the generative potential between positive organizational scholarship and management, spirituality, and religion research. Journal of Management, Spirituality and Religion. v. 11, n. 1, p. 6-26, 2014.

LENNICK, D.; KIEL, F. Moral intelligence: enhancing business performance and leadership success. Upper Saddle River: Wharton School Publishing, 2005.

LILIUS, J.M.; KANOV, J.; DUTTON, J.E.; WORLINE, M.C.; MAITLIS, S. Compassion revealed: what we know about compassion at work (and where we need to know more. In: CAMERON, K.S.; SPREITZER, G.M. (Eds.). The Oxford handbook of positive organizational scholarship. New York: Oxford University Press, 2012. p. 273-287. LILIUS, J.M.; WORLINE, M.C.; MAITLIS, S.; KANOV, J.; DUTTON, J.; FROST, P. The contours and consequences of compassion at work. Journal of Organizational Behavior, v. 29, n. 2, p. 193-218, 2008.

LINNENLUECKE, M.K. Resilience in business and management research: a review of influential publications and a research agenda. International Journal of Management Reviews, v. 19, n.1, p. 4-30, 2017.

LOPEZ, S.J.; PROSSER, E.C.; EDWARDS, L.M.; MAGYAR-MOE, J.L.; NEUFELD, J.E.; RASMUSSEN, H.N. Putting positive psychology in a multicultural context. In: SNYDER, C.R.; LOPEZ, S. J. (Eds.). Handbook of positive psychology. New York, NY: Oxford University Press, 2005. p. 700-714.

LUTHANS, F. The need for and meaning of positive organizational behavior. Journal of Organizational Behavior, v. 23, n. 6, p. 695-706, 2002.

LUTHANS, F.; VOLGELGESANG, G.R.; LESTER, P.B. Developing the psychological capital of resilience. Human Resource Development Review, v. 5, n. 1, p. 25-44, 2006. 
LUTHANS, F.; YOUSSEF, C.M.; AVOLIO, B.J. Psychological capital: investing and developing positive organizational behavior. In: NELSON, D. L.; COOPER, C. L. (Eds.). Positive organizational behavior. London: Sage, 2007. p. 9-24.

LYUBOMIRSKY, S.; KING, L.; DIENER, E. The benefits of frequent positive affect: does happiness lead to success? Psychological Bulletin, v. 131, n. 6, p. 803-855, 2005. MADDEN, L.T.; DUCHON, D.; MADDEN, T.M.; PLOWMAN, D.A. Emergent organizational capacity for compassion. Academy of Management Review, v. 37, n. 4, p. 683-708, 2012.

MANZ, C.C.; CAMERON, K.S.; MANZ, K.P.; MARX, R.D. (Eds.). The virtuous organization: insights from some of the world's leading management thinkers. Hackensack, NJ: World Scientific Publishing, 2008.

MOWBRAY, D. Building resilience - an organisational cultural approach to mental health and well-being at work: a primary prevention programme. In: A. KINDER, R. HUGHES, AND C.L. COOPER (Eds.). Employee well-being support: a workplace resource. West Sussex: John Wiley \& Sons, 2008. p. 309-321

NAKAMURA, J.; CSIKSZENTMIHALYI, M. The construction of meaning through vital engagement. In: KEYES, C.L.M.; HAIDT, J. (Eds.). Flourishing: positive psychology and the life well-lived. Washington, DC: American Psychological Association, 2003. p. 83-104. NEVILLE, M.G. Positive deviance on the ethical continuum: Green Mountain Coffee as a case study in conscientious capitalism. Business and Society Review, v. 113, n. 4, p. 555576, 2008.

NIESSEN, C.; SONNENTAG, S.; SACH, F. Thriving at work-A diary study. Journal of Organizational Behavior, v. 33, n. 4, p. 468-487, 2012.

NILSSON, W. Positive institutional work: exploring institutional work through the lens of positive organizational scholarship. Academy of Management Review, v. 40, n. 3, p. 370 $398,2015$.

OLLIER-MALATERRE, A. Contributions of work-life and resilience initiatives to the individual/organisation relationship. Human Relations, v. 63, n. 1, p. 41-62, 2010.

PALANSKI, M.E. Forgiveness and reconciliation in the workplace: a multi-level perspective and research agenda. Journal of Business Ethics, v. 109, n. 3, p. 275-287, 2012.

PARK, N.; PETERSON, C.M. Virtues and organizations. In: CAMERON, K.S.; DUTTON, J. E.; QUINN, R.E. (Eds.). Positive Organizational Scholarship. San Francisco: BerrettKoelher, 2003. p. 33-47. 
PATERSON, T.A.; LUTHANS, F.; JEUNG, W. Thriving at work: impact of psychological capital and supervisor support. Journal of Organizational Behavior, v. 35, n. 3, p. 434-446, 2014.

PATTON, M.Q. Qualitative evaluation and research methods, 3rd edition. Thousand Oaks: Sage, 2002.

PETERSON, C.M.; SELIGMAN, M.E.P. Positive organizational studies: lessons from positive psychology. In: CAMERON, K.S.; DUTTON, J. E.; QUINN, R.E. (Eds.). Positive organizational scholarship. San Francisco: Berrett-Koelher, 2003. p. 14-27.

PORATH, C.L. Civility. In: CAMERON, K.S.; SPREITZER, G.M. (Eds.). The Oxford handbook of positive organizational scholarship. New York: Oxford University Press, 2012. p. 439-448.

POWLEY, E.H.; CAMERON, K.S. Organizational healing: lived virtuous amidst organizational crisis. Journal of Management, Spirituality, and Religion, v. 3, n. 1-2, p. 13-33, 2006.

PRATT, M.G.; ASHFORTH, B. Fostering meaningfulness in working and at work. In: CAMERON, K.S.; DUTTON, J. E.; QUINN, R.E. (Eds.). Positive organizational scholarship. San Francisco: Berrett-Koelher, 2003. p. 309-327.

PRATT, M.G.; DIRKS, K.T. Rebuilding trust and restoring positive relationships: a commitment-based view of trust. In: DUTTON, J. E.; RAGINS, B. R. (Eds.). Exploring positive relationships at work: building a theoretical and research foundation. Mahwah, NJ: Lawrence Erlbaum Associate, 2007. p.117-136.

QUINN, R.E.; WELLMAN, N. Seeing and acting differently: positive change in organizations. In: CAMERON, K.S.; SPREITZER, G.M. (Eds.). The Oxford Handbook of Positive Organizational Scholarship. New York: Oxford University Press, 2012. p. 751762.

RAGINS, B.R.; DUTTON, J.E. Positive relationships at work: an introduction and invitation. In: DUTTON, J. E.; RAGINS, B. R. (Eds.). Exploring positive relationships at work: building a theoretical and research foundation. Mahwah, NJ: Lawrence Erlbaum Associate, 2007. p. 3-25.

RAMBUR, B.; VALLETT, C.; COHEN, J.A.; TARULE, J. The moral cascade: distress, eustress, and the virtuous organization. Journal of Organizational Moral Psychology, v. 1, n. 1 , p. $41-54,2010$. 
REGO, A.; RIBEIRO, N.; CUNHA, M.P.; JESUINO, J.C. How happiness mediates the organizational virtuousness and affective commitment relationship. Journal of Business Research, v. 64, n. 5, p. 524-532, 2011.

RHEE, S.Y.; DUTTON, J.E.; BAGOZZI, R.P. Making sense of organizational actions with virtue frames and its links with organizational attachment. In: MANZ, C.C.; CAMERON, K.S.; MANZ, K.P.; MARX, R.D. (Eds.). The virtuous organization: insights from some of the world's leading management thinkers. Hackensack: World Scientific Publishing, 2008. p. 45-65.

ROBERTS, C.R. The blessings of gratitude: a conceptual analysis. In R.A. Emmons and M.E. McCullough (Eds.), The Psychology of Gratitude. Oxford University Press: New York, NY, p. 58-78, 2004.

ROSSO, B.D.; DEKAS, K.H.; WRZESNIEWSKI, A. On the meaning of work: a theoretical integration and review. Research in Organizational Behavior, v. 30, p. 91-127, 2010. RYFF, C.D.; SINGER, B. Flourishing under fire: resilience as a prototype of challenged thriving. In: KEYES, C.L.M.; HAIDT, J. (Eds.). Flourishing: positive psychology and the life well-lived. Washington, DC: American Psychological Association, 2003. p. 15-36. RYNES, S.L.; BARTUNEK, J.M.; DUTTON, J.E.; MARGOLIS, J.D. Care and compassion through an organizational lens: opening up new possibilities. Academy of Management Review, v. 37, n. 4, p. 503-523, 2012.

SCHILPZAND, P.; HEKMAN, D.R.; MITCHELL, T.R. An inductively generated typology and process model of workplace courage. Organization Science, v. 26, n.1, p. 52-77, 2015. SEKERKA, L.E. Preserving integrity in the face of corruption: exercising moral muscle in the path to right action. Journal of Organizational Moral Psychology, v. 1, n. 3, p. 1-14, 2010 .

SEKERKA, L.E.; BAGOZZI, R.P.; CHARNIGO, R. Facing ethical challenges in the workplace: conceptualizing and measuring professional moral courage. Journal of Business Ethics, v. 89, n. 4, p. 565-579, 2009.

SEKERKA, L.E.; FREDRICKSON, B.L. Creating transformative cooperation through positive emotions. In: PIDERIT, S. K.; FRY, R. E.; COOPERRIDER, D. L. (Eds.).

Handbook of transformative cooperation. Stanford, CA: Stanford University Press, 2007. p. 151-169.

SEKERKA, L.E.; FREDRICKSON, B.L. Establishing positive emotional climates to advance organizational transformation. In: ASHKANASY, N.A.; COOPER, C.L. (Eds.). Research 
companion to emotion in organizations. Northampton: Edward Elgar Publishing, 2008. p. $531-545$.

SEKERKA, L.E.; VACHARKULKSEMSUK, T.; FREDRICKSON, B.L. Positive emotions: broadening and building upward spirals of sustainable enterprise. In: CAMERON, K.S.; SPREITZER, G.M. (Eds.). The Oxford Handbook of Positive Organizational Scholarship. New York: Oxford University Press, 2012. p. 168-177.

SELIGMAN, M.E.P. Foreword: the past and future of positive psychology. In: KEYES, C.L.M.; HAIDT, J. (Eds.). Flourishing: positive psychology and the life well-lived. Washington, DC: American Psychological Association, 2003. p. xi-xx.

SELIGMAN, M.E.P.; CSIKSZENTMIHALYI, M. Positive psychology: an introduction. American Psychologist, v. 55, n. 1, p. 5-14, 2000.

SHAHZAD, K.; MURAD, H.S.; KITCHLEW, N.; ZIA, S.A. Integrating principles of care, compassion and justice in organizations: exploring dynamic nature of organizational justice. Journal of Human Values, v. 20, n. 2, p. 167-181, 2014.

SIMMONS, B.L.; NELSON, D.L. Eustress at work: extending the holistic stress model. In: NELSON, D. L.; COOPER, C. L. (Eds.). Positive organizational behavior. London: Sage, 2007. p. 40-53.

SIMPSON, A.V.; CLEGG, S.; PITSIS, T. 'I used to care but things have changed': a genealogy of compassion in organizational theory. Journal of Management Inquiry, v. 23, n. 4, p. 347-359, 2014.

SIMPSON, A.V.; CUNHA, M.P.; REGO, A. Compassion in the context of capitalistic organizations: evidence from the 2011 Brisbane Floods. Journal of Business Ethics, v. 130, n. 3, p. 683-703, 2015.

SIMS, R.L. A study of deviance as a retaliatory response to organizational power. Journal of Business Ethics, v. 92, n. 4, p. 553-563, 2010.

SOLOMON, R.C. The moral psychology of business: care and compassion in the corporation. Business Ethics Quarterly, v. 8, n.3, p. 515-533, 1998.

SPREITZER, G.M.; LAM, C.F.; QUINN, R.W. Human energy in organizations: implications for POS from six interdisciplinary streams. In: CAMERON, K.S.; SPREITZER, G.M. (Eds.). The Oxford Handbook of Positive Organizational Scholarship. New York: Oxford University Press, 2012. p. 155-167.

SPREITZER, G.M.; SONENSHEIN, S. Positive deviance and extraordinary organizing. In: CAMERON, K.S.; DUTTON, J. E.; QUINN, R.E. (Eds.). Positive Organizational Scholarship. San Francisco: Berrett-Koelher, 2003. p. 207-224. 
SPREITZER, G.M.; SONENSHEIN, S. Toward the construct definition of positive deviance. American Behavioral Scientist, v. 47, n. 6, p. 828-847, 2004.

SPREITZER, G.M.; SUTCLIFFE, K.M. Thriving in organizations. In: NELSON, D. L.; COOPER, C. L. (Eds.). Positive organizational behavior. London: Sage, 2007. p. 74-85. SPREITZER, G.M.; SUTCLIFFE, K.M.; DUTTON, J., SONENSHEIN, S.; GRANT, A.M. A socially embedded model of thriving at work. Organization Science, v. 16, n. 5, p. 537-549, 2005.

SUTCLIFFE, K.M.; VOGUS, T.J. Organizing for resilience. In: CAMERON, K.S.; DUTTON, J. E.; QUINN, R.E. (Eds.). Positive Organizational Scholarship. San Francisco: Berrett-Koelher, 2003. p. 94-110.

VADERA, A.K.; PRATT, M.G.; MISHRA, P. Constructive deviance in organizations: integrating and moving forward. Journal of Management, v. 39, n. 5, p. 1221-1276, 2013. VALENTINE, S.; GODKIN, L.; FLEISCHMAN, G.M.; KIDWELL, R. Corporate ethical values, group creativity, job satisfaction and turnover intention: the impact of work context on work response. Journal of Business Ethics, v. 98, n. 3, p. 353-372, 2011.

VASCONCELOS, A. F. Espiritualidade no ambiente de trabalho: dimensões, reflexões e desafios. São Paulo: Editora Atlas, 2008.

VASCONCELOS, A.F. The spiritually-based organization: a theoretical review and its potential role in the third millennium. Cadernos EBAPE.BR, v. 13, n. 1, p. 183-205, 2015. WALLS, J.L.; HOFFMAN, A.J. Exceptional boards: environmental experience and positive deviance from institutional norms. Journal of Organizational Behavior, v. 34, n. 2, p. 253 $271,2013$.

WARREN, D.E. Constructive and destructive deviances in organizations. Academy of Management Review, v. 28, n. 4, p. 622-632, 2003.

WILSON, S.M.; FERCH, S.R. Enhancing resilience in the workplace through the practice of caring relationships. Organization Development Journal, v. 23, n. 4, p. 45-60, 2005.

WORLINE, M.C. Courage in organizations: an integrative review of the 'difficult virtue'. In: CAMERON, K.S.; SPREITZER, G.M. (Eds.). The Oxford handbook of positive organizational scholarship. New York: Oxford University Press, 2012. p. 304-315. WORLINE, M.C.; QUINN, R.W. Courageous principled action. In: CAMERON, K.S.; DUTTON, J. E.; QUINN, R.E. (Eds.). Positive organizational scholarship. San Francisco: Berrett-Koelher, 2003. p. 138-157.

WORLINE, M.C.; WRZESNIEWSKI, A.; RAFAELI, A. Courage and work breaking routines to improve performance. In: LORD, R. G.; J. KLIMOSKI, J.; KANFER, R. (Eds.). 
Emotions in the workplace: understanding the structure and role of emotions in organizational behavior. San Francisco, CA: Jossey-Bass, 2002. p. 295-330.

WORTHINGTON Jr., E.L.; BERRY, J.W.; SHIVY, V.A.; BROWSTEIN, E. Forgiveness and positive psychology in business ethics and corporate social responsibility. In; GIACALONE, R. A.; C.L. JURKIEWICZ, C. L.; C. DUNN, C. (Eds.). Positive psychology in business ethics and corporate responsibility. Greenwich: Information Age Publishing, 2005. p. 265-284.

WRIGHT, T.; CROPANZANO, R. The role of psychological well-being in job performance: a fresh look at an age-old quest. Organizational Dynamics, v. 33, n. 4, p. 338-351, 2004. WRIGHT, T.A.; GOODSTEIN, J. Character is not 'dead' in management research: a review of individual character and organizational-level virtue. Journal of Management, v. 33, n. 6, p. 928-958, 2007.

WRZESNIEWSKI, A. Callings. In: CAMERON, K.S.; SPREITZER, G.M. (Eds.). The Oxford handbook of positive organizational scholarship. New York: Oxford University Press, 2012. p. 45-55.

WRZESNIEWSKI, A.; ROZIN, P.; BENNETT, G. Working, playing, and eating: making the most of most moments. In: KEYES, C.L.M.; HAIDT, J. (Eds.). Flourishing: positive psychology and the life well-lived. Washington, DC: American Psychological Association, 2003. p. 185-204.

YOUSSEF, C.M.; LUTHANS, F. A positive organizational behavior approach to ethical performance. GIACALONE, R. A.; C.L. JURKIEWICZ, C. L.; C. DUNN, C. (Eds.). Positive psychology in business ethics and corporate responsibility. Greenwich: Information Age Publishing, 2005. p. 1-22. 